\title{
Mild water stress-induced priming enhance tolerance to Rosellinia necatrix in susceptible avocado rootstocks
}

\author{
E. Martínez-Ferri' ${ }^{1}$ G. Moreno-Ortega ${ }^{1}$, N. van den Berg ${ }^{2,3}$ and C. Pliego ${ }^{1 *}$
}

\begin{abstract}
Background: White root rot (WRR) disease caused by Rosellinia necatrix is one of the most important threats affecting avocado orchards in temperate regions. The eradication of WRR is a difficult task and environmentally friendly control methods are needed to lessen its impact. Priming plants with a stressor (biotic or abiotic) can be a strategy to enhance plant defense/tolerance against future stress episodes but, despite the known underlying common mechanisms, few studies use abiotic-priming for improving tolerance to forthcoming biotic-stress and vice versa ('cross-factor priming). To assess whether cross-factor priming can be a potential method for enhancing avocado tolerance to WRR disease, 'Dusa' avocado rootstocks, susceptible to $R$. necatrix, were subjected to two levels of water stress (mild-WS and severe-WS) and, after drought-recovery, inoculated with R. necatrix. Physiological response and expression of plant defense related genes after drought-priming as well as the disease progression were evaluated.

Results: Water-stressed avocado plants showed lower water potential and stomatal limitations of photosynthesis compared to control plants. In addition, NPQ and qN values increased, indicating the activation of energy dissipating mechanisms closely related to the relief of oxidative stress. This response was proportional to the severity of the water stress and was accompanied by the deregulation of pathogen defense-related genes in the roots. After re-watering, leaf photosynthesis and plant water status recovered rapidly in both treatments, but roots of mild-WS primed plants showed a higher number of overexpressed genes related with plant defense than severeWS primed plants. Disease progression after inoculating primed plants with $R$. necatrix was significantly delayed in mild-WS primed plants.

Conclusions: These findings demonstrate that mild-WS can induce a primed state in the WRR susceptible avocado rootstock 'Dusa' and reveal that 'cross-factor priming' with water stress (abiotic stressor) is effective for increasing avocado tolerance against $R$. necatrix (biotic stressor), underpinning that plant responses against biotic and abiotic stress rely on common mechanisms. Potential applications of these results may involve an enhancement of WRR tolerance of current avocado groves and optimization of water use via low frequency deficit irrigation strategies.
\end{abstract}

Keywords: Abiotic and biotic stress, Drought recovery, Fungal pathogens, Gene expression, Priming, Physiological response, White root rot

\footnotetext{
* Correspondence: mclara.pliego@juntadeandalucia.es

'IFAPA. Centro de Málaga. Cortijo de la Cruz s/n, 29140 Churriana, Málaga,

Spain

Full list of author information is available at the end of the article
}

(C) The Author(s). 2019 Open Access This article is distributed under the terms of the Creative Commons Attribution 4.0 International License (http://creativecommons.org/licenses/by/4.0/), which permits unrestricted use, distribution, and reproduction in any medium, provided you give appropriate credit to the original author(s) and the source, provide a link to the Creative Commons license, and indicate if changes were made. The Creative Commons Public Domain Dedication waiver (http://creativecommons.org/publicdomain/zero/1.0/) applies to the data made available in this article, unless otherwise stated. 


\section{Background}

Avocado (Persea americana Mill.), a member of the Lauraceae family, is a very important fruit crop consumed worldwide in more than 50 countries. Avocado fruit is considered to be one of the top 15 healthiest foods according to surveys across the United States and Western Europe [1] and is becoming a key component of the consumer's diet in many countries. Avocado health benefits have triggered its consumption in recent years $(\sim 4.6 \%$ increase of worldwide consumption every year; $\sim 25 \%$ increase in Europe [2];) but production remains a step behind ( $4.5 \%$ increase per year [3];), which raises concerns about the difficulties of satisfying this demand in the near future.

This gap between production and demand is aggravated by the incidence of avocado diseases, the soilborne pathogen Phytophthora cinnamomi Rands (Phytophthora root rot; PRR) being one of the major limiting factors of avocado production worldwide [4]. Given the importance of this pathogen, many studies have been focused on the control of PRR and positive results, derived from an integrated approach involving the use of phosphate, proper field management and commercially available rootstocks with partial tolerance to P. cinnamomi ('Thomas', 'Duke 7' and 'Dusa') $[5,6]$, have been achieved.

Another important soilborne disease affecting avocado groves in productive temperate regions such as South Africa, Israel, Italy and Spain (avocado exporters to the European market), is the white root rot (WRR) caused by Rosellinia necatrix Prill $[7,8]$.. In contrast to $P$. cinna$m o m i$, control of this disease is a complex and difficult task, and, to date, no completely effective control methods have been developed [8, and references therein]. As for $P$. cinnamomi, breeding for $R$. necatrix tolerant rootstocks could represent an effective method for controlling the spread of this pathogen [9] but, although a breeding program is ongoing in Spain (Andalusian Institute of Agricultural Research and Training; IFAPA), no commercial rootstocks are currently available. Thus, alternative approaches, focused on achieving environmentally friendly strategies to decrease WRR incidence in avocado production areas, are necessary.

In this regard, many studies have shown that the preexposure of plants to a stress-inducing factor (priming concept) [10-12] allows them to become more tolerant to forthcoming biotic (i.e. pathogens $[10,13])$ or abiotic (i.e. water stress, chemical compounds [14, 15]) stress episodes. This priming-induced tolerance seems to be associated with a more rapid and robust activation of cellular defense responses in primed plants compared to non-primed ones $[11,12,16]$. Although the mechanisms underlying the induction of the priming state are complex and diverse [17], it is well known that plant stress responses to biotic or abiotic factors share common pathways [18, 19] and even cross-tolerance can be achieved [20, 21]. For instance, levels of salicylic acid (SA), associated with reactive oxygen species (ROS) signalling and with the regulation of important plant physiological processes [22, 23], have been reported to increase under drought stress [18, 24-26] and pathogen attack [27-30]. More concretely, the accumulation of SA induces the transcription of non-expressor of pathogenesis related gene 1 (NPR1) that further activates genes encoding pathogenesis-related (PR) proteins [31, 32], shown to play an important role in either biotic [33-37] or abiotic stress [38-42] responses. Particularly, avocado tolerance to $P$. cinnamomi and $R$. necatrix has been linked to the induction of PR-genes and protease inhibitors, respectively $[19,43]$; both are related with other abiotic stresses such as water stress $[44,45]$. Thus, it is possible that exposure to one type of stress (i.e. abiotic stressor) could activate plant responses enabling tolerance to different types of forthcoming stresses (i.e. biotic stressor [46];); hereinafter referred as 'cross-factor priming'. In fact, it has been reported that drought-primed Eucaliptus plants were more resistant to Neofusicoccum fungal infection compared to non-primed ones [16].

In this context, the present study aims to test whether drought-priming could be used in avocado to increase tolerance to WRR disease. For this purpose, the role of drought-priming in $R$. necatrix interaction with the susceptible avocado 'Dusa' rootstock was evaluated by assessing physiological status, stress-related gene expression, and disease progression response.

\section{Results}

Physiological response of avocado 'Dusa' rootstocks to mild and severe water stress levels and recovery after rewatering

To investigate the priming-induced response of 'Dusa' rootstock by mild and severe water stress (mild-WS and severe-WS), two sets of well irrigated plants (at field capacity, Fc $\sim 0.4 \mathrm{v} / \mathrm{v})$ were subjected to water deprivation until soil water content (SWC) reached 50 and $25 \%$ of Fc, respectively (Fig. 1). Throughout the experiment, a set of plants were irrigated daily to act as controls whereas, in the two sets of water-stressed plants, water lessening was done progressively to attain both water stress levels concurrently (after a 6 day lag; Fig. 2). Once these levels were reached, plants were rewatered and Fc values were achieved immediately. Daily irrigation was restored in all plants until inoculation with $R$. necatrix.

Physiological measurements were taken on the two water-stress levels and after re-watering. In consonance with the water stress severity, midday water potential decreased significantly compared to control plants $(P<$ $0.05)$ reaching $-1.01 \pm 0.03 \mathrm{MPa}$ in mild-WS and - 

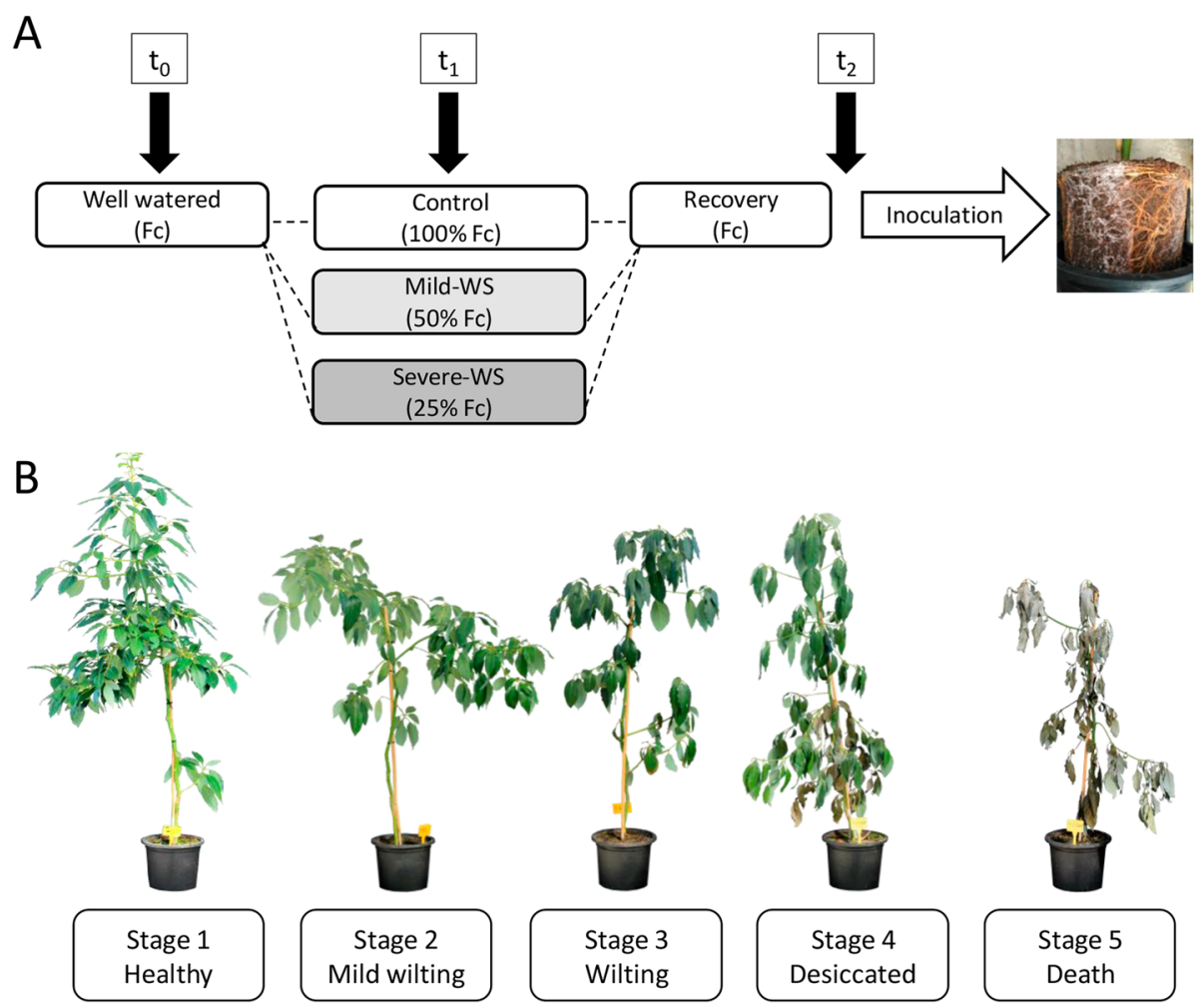

Fig. 1 Schematic illustration of the experimental design (a) and stages of aerial symptoms in 'Dusa' plants inoculated with R. necatrix (b). Control plants were watered to field capacity (Fc) throughout the experiment and water stressed plants were subjected to controlled substrate drying-up until they reached $50 \%$ of Fc (mild-WS) and $25 \%$ of Fc (severe-WS), respectively ( $\mathrm{t}_{1}$ ). Afterwards, all plants were fully irrigated to assess drought recovery response $\left(\mathrm{t}_{2}\right)$ and to carry out the pathogenicity test with $R$. necatrix

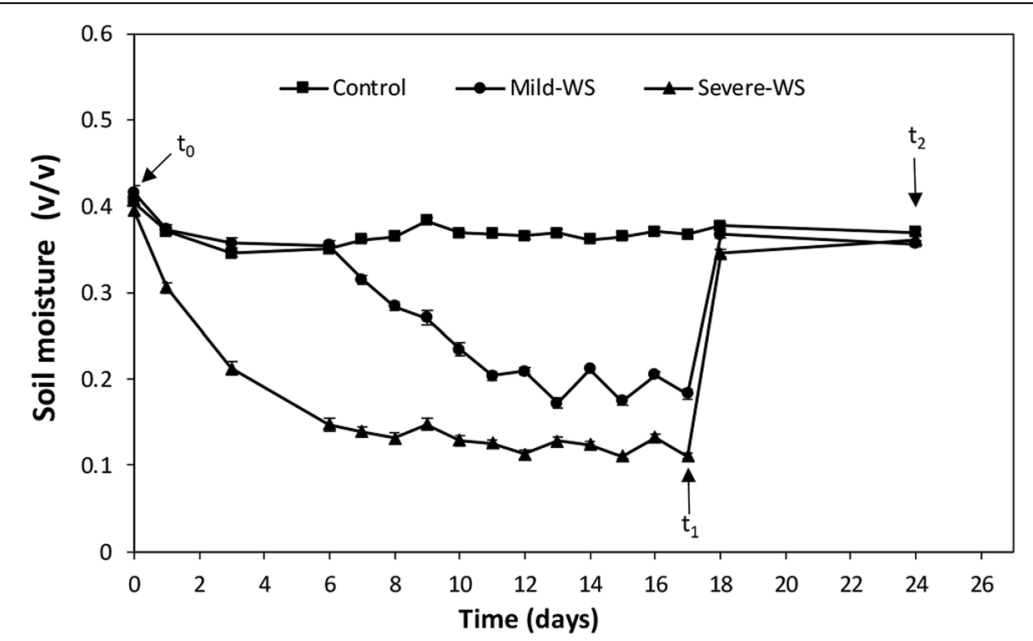

Fig. 2 Time-course of mean values ( \pm SE) of volumetric soil moisture of 'Dusa' non-stressed control plants $(n=36)$ and subjected to two water stress (WS) treatments: mild-WS and severe-WS $(n=38)$. The arrows indicate the time points where plants physiological status $\left(\mathrm{t}_{0}\right)$, physiological measurements and root samplings $\left(t_{1}, t_{2}\right)$ were done 
$2.06 \pm 0.09 \mathrm{MPa}$ in severe-WS (Fig. 3a). Consistently, net $\mathrm{CO}_{2}$ assimilation rates $\left(A_{\mathrm{N}}\right)$ and stomatal conductance $\left(g_{\mathrm{s}}\right)$ showed a marked and significant decrease in both stress levels $(P<0.05$; Fig. $3 \mathrm{~b}, \mathrm{c}), A_{\mathrm{N}}$ being reduced in more than $\sim 70 \%$ and $\sim 90 \%$, in mild-WS and severeWS, respectively, while $g_{\mathrm{s}}$ was almost completely supressed in both treatments. Leaf relative water content (RWC) decreased only significantly $(P<0.05)$ in the severe-WS treatment showing values of $87.5 \pm 0.85 \%$ whereas in control and mild-WS, values were $~ 94 \%$.
At the photochemical level, dark-adapted photochemical efficiency of photosystem II (PSII; $F_{\mathrm{v}} / F_{\mathrm{m}}$ ) was not significantly affected by water stress and mean values were close to 0.82 in all treatments (Table 1), indicating that water stress levels did not entail chronic photoinhibition. The relative quantum yield of PSII photochemistry (ФPSII) was not affected in the mild-WS treatment but was significantly reduced in the severeWS (Table 1). Water stress treatments did not have an effect on the fraction of PSII centres in the open state

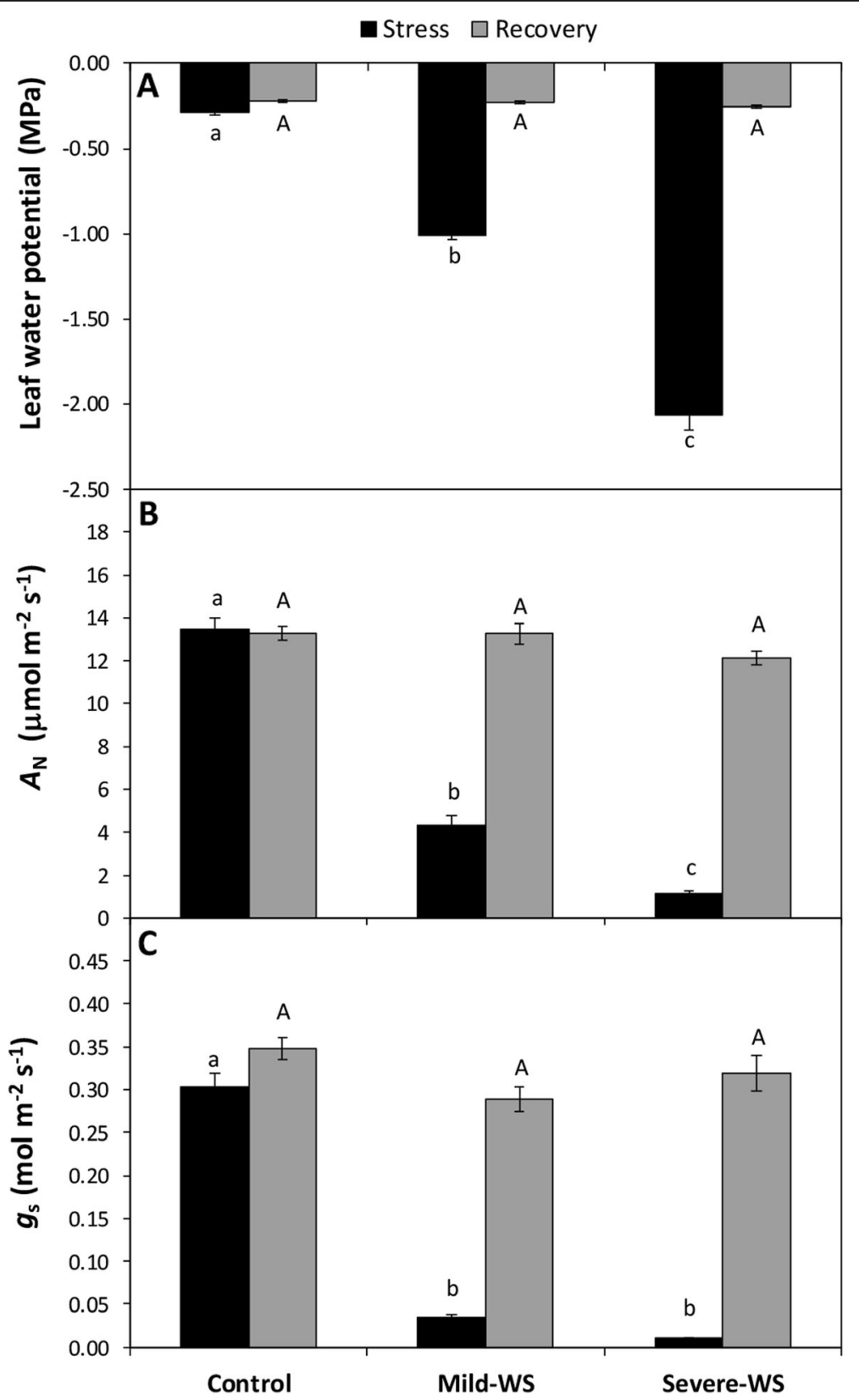

Fig. 3 Midday water potential $(\mathbf{a})$, net $\mathrm{CO}_{2}$ assimilation rate $\left(A_{N} ; \mathbf{b}\right)$ stomatal conductance $\left(g_{s ;} \mathbf{c}\right)$ of 'Dusa' plants in control, mild-WS and severeWS water treatments. Black and grey bars show mean values $( \pm \mathrm{SE}, n=30)$ under stress and after recovery, respectively. Within each series, different capital or lowercase letters indicate significant differences among treatments $(P<0.05$; one-way ANOVA followed by LSD) 
Table 1 Maximal photochemical efficiency of PSII $\left(F_{\mathrm{v}} / F_{\mathrm{m}}\right)$, relative quantum yield of PSIl photochemistry $(\phi P S I I)$, maximum photochemical efficiency of the open reaction centres of PSII $\left(F_{v}{ }^{\prime} / F_{m}\right)$, fraction of PSII centres in open state $(q L)$, non-photochemical fluorescence quenching (NPQ) and coefficient of non-photochemical fluorescence quenching $(q \mathrm{~N})$ in control non-stressed plants, water stressed plants (mild-WS and severe-WS) and drought-primed plants (recovery mild-WS and severe-WS)

\begin{tabular}{|c|c|c|c|c|c|c|c|c|c|c|c|c|c|c|c|}
\hline \multirow[b]{2}{*}{$F_{v} / F_{m}$} & \multicolumn{3}{|c|}{ Control } & \multicolumn{3}{|c|}{ Mild-WS } & \multicolumn{3}{|c|}{ Severe-WS } & \multicolumn{3}{|c|}{ Recovery Mild-WS } & \multicolumn{3}{|c|}{ Recovery Severe-WS } \\
\hline & 0.821 & \pm & 0.00 & 0.820 & \pm & 0.00 & 0.817 & \pm & 0.00 & 0.825 & \pm & 0.00 & 0.825 & \pm & 0.00 \\
\hline$\overline{\phi P S \|}$ & 0.566 & \pm & $0.01^{\mathrm{a}}$ & 0.556 & \pm & $0.01^{\mathrm{a}}$ & 0.459 & \pm & $0.02^{\mathrm{b}}$ & 0.562 & \pm & $0.01^{\mathrm{a}}$ & 0.547 & \pm & $0.01^{\mathrm{a}}$ \\
\hline$F_{v}^{\prime} / F_{m}{ }^{\prime}$ & 0.696 & \pm & $0.01^{\mathrm{a}}$ & 0.661 & \pm & $0.01^{b}$ & 0.597 & \pm & $0.01^{c}$ & 0.703 & \pm & $0.01^{\mathrm{a}}$ & 0.698 & \pm & $0.01^{\mathrm{a}}$ \\
\hline$q L$ & 0.587 & \pm & $0.03^{\mathrm{ab}}$ & 0.649 & \pm & $0.03^{\mathrm{a}}$ & 0.584 & \pm & $0.03^{\mathrm{ab}}$ & 0.550 & \pm & $0.02^{\mathrm{b}}$ & 0.533 & \pm & $0.03^{b}$ \\
\hline$N P Q$ & 0.510 & \pm & $0.03^{c}$ & 0.785 & \pm & $0.05^{\mathrm{b}}$ & 1.224 & \pm & $0.09^{\mathrm{a}}$ & 0.581 & \pm & $0.05^{c}$ & 0.599 & \pm & $0.04^{c}$ \\
\hline$q N$ & 0.413 & \pm & $0.02^{c}$ & 0.534 & \pm & $0.02^{\mathrm{b}}$ & 0.655 & \pm & $0.02^{\mathrm{a}}$ & 0.439 & \pm & $0.02^{c}$ & 0.455 & \pm & $0.02^{c}$ \\
\hline
\end{tabular}

Each value is the mean \pm SE (controls $n=36$, treatments $n=38$ ). Different letters indicate significant differences among treatments within rows $(P<0.05)$

( $q \mathrm{~L}$ [47];) while the reverse was true for the maximum photochemical efficiency of the open reaction centres of PSII $\left(F_{\mathrm{v}}{ }^{\prime} / F_{\mathrm{m}}{ }^{\prime}\right)$, which was significantly reduced as water stress became more severe (Table 1). These changes in $F_{\mathrm{v}}{ }^{\prime} / F_{\mathrm{m}}{ }^{\prime}$ were accompanied by a concomitant increase in other non-photochemical quenching related parameters (NPQ and $q \mathrm{~N}$; Table 1).

Relative chlorophyll content (SPAD index) and leaf mass area (LMA) did not differ significantly between control and water stressed plants and no symptoms of leaf chlorosis were observed in any of the water stress treatments. Average SPAD values in all treatments were $59.4 \pm 0.1$ and LMA ranged from $76.8 \mathrm{~g} \mathrm{~m}^{-2}$ to $83.4 \mathrm{~g} \mathrm{~m}^{-2}$.

Within one week after re-watering and prior to inoculation with $R$. necatrix, all physiological parameters of stressed plants recovered similar values to those of control plants (Table 1 and Fig. 3). Hereinafter, these waterstressed-recovered plants will be referred as 'primed plants'.

\section{Molecular response of avocado 'Dusa' rootstocks to mild and severe water stress and recovery after re-watering} The expression of thirteen defense-related genes on roots of 'Dusa' avocado rootstock subjected to mild-WS and severe-WS and one week after re-watering, was analysed by performing a real time quantitative qPCR (qRTPCRs). This selection included induced genes indicated in previous studies with 'BG83' (tolerant to $R$. necatrix) and 'Dusa' (tolerant to $P$. cinnamomi) avocado rootstocks after infection with the soilborne pathogens $R$. necatrix [43] and P. cinnamomi, respectively [19, 4850]. In addition to their implication in pathogen defense, some of the selected genes are also involved in salt, oxidative, osmotic and water stress responses (Table 2).

Five primers were taken from literature and eight were developed in this research (Additional file 1: Table S1). The actin gene was used as an endogenous constitutive gene to normalize the expression results, and negative controls were used to confirm the absence of contamination. The relative quantification for the expression of the selected genes by the $\Delta \Delta \mathrm{Ct}$ method is shown in Table 2. Water deprivation on avocado roots caused a significant repression of 6 and 3 genes in roots subjected to mild-WS and severe-WS, respectively (Table 2), with gene Contig00582, encoding the $\mathrm{BTB} / \mathrm{POZ}$ and TAZ domain-containing protein 1-like, showing the highest repression in both treatments. In contrast, transcript levels of 6 genes (protease inhibitor-like, glutathione s-transferase, metallothionein like protein, NAC domain-containing protein 72 , universal stress protein and miraculin) were significantly induced under both levels of water stress (Table 2 and Fig. 4).

Different gene expression patterns were detected in avocado roots of primed plants, in which the number of significantly repressed genes was reduced to two in both, mild-WS and severe-WS primed plants. A higher number of significantly overexpressed genes was observed in roots of mild-WS primed plants, being induced eight genes among which, four were repressed under water stress (NPR1, PR4, PR5, endochitinase). The highest induction level was found for the NAC domain containing protein 72, reaching fold change (FC) value of 177 in qRT-PCR experiments. Only three of the study genes (protease inhibitor-like, universal stress protein and miraculin) were significantly induced in roots of severe-WS primed plants.

\section{Pathogenicity test on water stress primed 'Dusa' avocado rootstocks}

In order to test whether priming with mild-WS and severeWS could be used to induce tolerance to $R$. necatrix in avocado 'Dusa' rootstock, primed avocado plants were inoculated with wheat grains infected with $R$. necatrix. Disease progression was slightly faster in severe-WS primed plants than in non-primed control plants. Thus, visible aboveground WRR symptoms appeared 42 and 53 days postinoculation, respectively. After 60 days post-inoculation, $50 \%$ of the non-primed control plants and severe-WS primed plants showed visible aerial symptoms (Fig. 5a). 


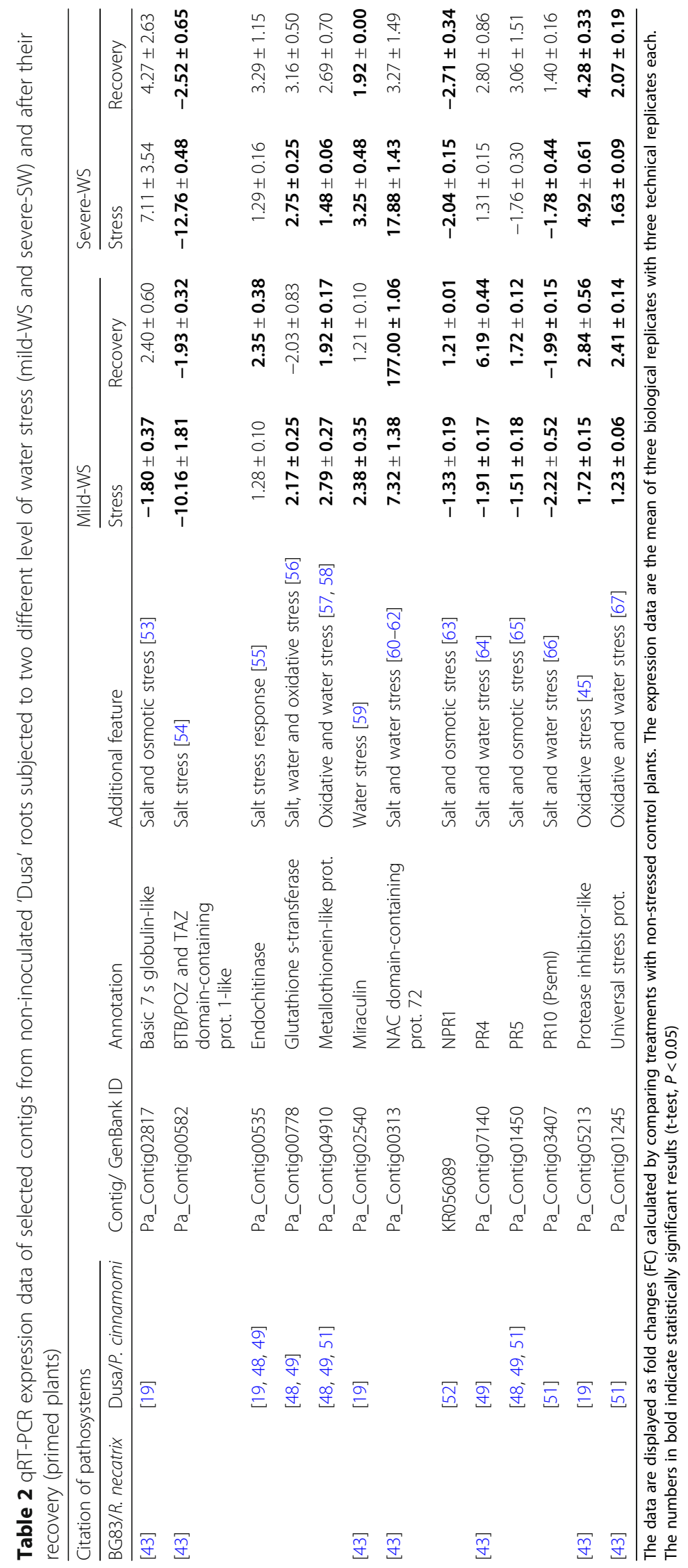




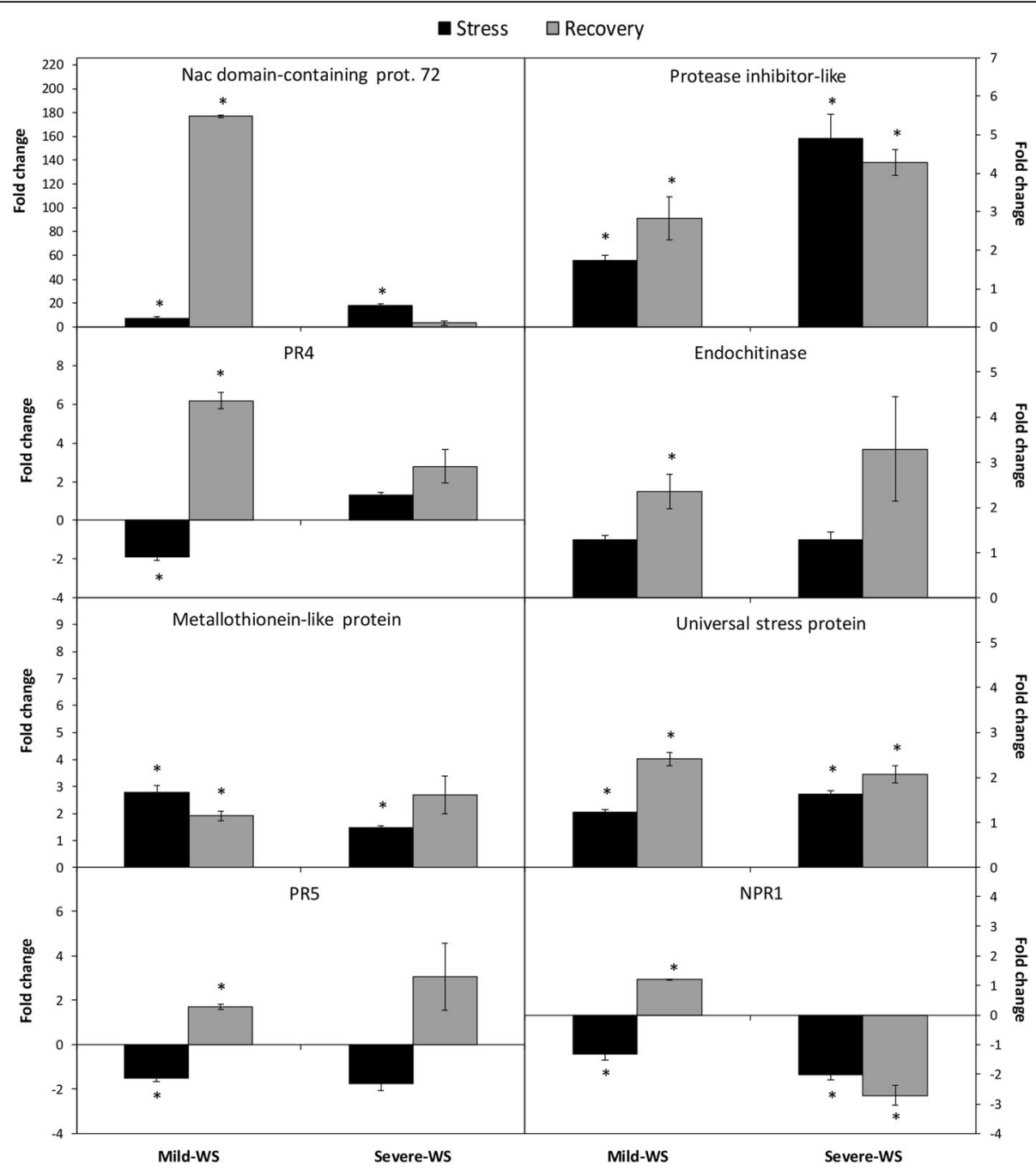

Fig. 4 Gene expression analysis by qRT-PCR assay of eight selected genes in 'Dusa' plants subjected to two levels of water stress (WS), mild-WS and severe-WS and recovery after re-watering. Data are displayed as fold change (FC) calculated by comparing treatments with non-stressed control plants. The expression data are the mean $( \pm \mathrm{SE}, n=9)$ of three biological replicates with three technical replicates each. Asterisk indicate statistical differences to control plants (Student's t-test, $P<0.05$ )

Priming plants with mild-WS showed improved tolerance to WRR as indicated by a significant reduction in the area under disease progress curve (AUDPC) values $(P<0.05)$ (Fig. 5b). Although visible wilting symptoms in some leaves appeared 48 days post inoculation, $50 \%$ of the plants displayed aboveground WRR symptoms after 75 days post-inoculation ( 30 days after the first visible symptoms). After three and a half months post inoculation all non-primed control and severe-WS primed plants were at stage 5 (dead), while some mild-WS primed plants remained at stage 3 .

\section{Discussion}

Plants have evolved diverse strategies to cope with different environmental stresses, but many studies have shown that most plant responses to biotic and abiotic stress rely on an assortment of common physiological and molecular mechanisms $[18,19]$. Particularly, it has been reported that avocado 'Dusa' rootstock response to $R$. necatrix infection involves the impairment of water relations and photosynthesis [68-70] as well as the induction of genes related to water stress and pathogen defense responses [43]. These findings are in agreement with results of the present study on the response of 'Dusa' avocado to water stress. This response was dependent upon water stress intensity, since mild-WS and severe-WS treatments affected leaf water status differentially (i.e. decreased values of leaf water potential and RWC) as well as photosynthetic performance, shown by the enhancement of photoprotective mechanisms (i.e. NPQ and $q \mathrm{~N}$ values) and the decrease in gas exchange parameters (i.e. $A_{\mathrm{N}}$ and $g_{\mathrm{s}}$ ). These physiological changes are consistent to those previously described in response to mild 

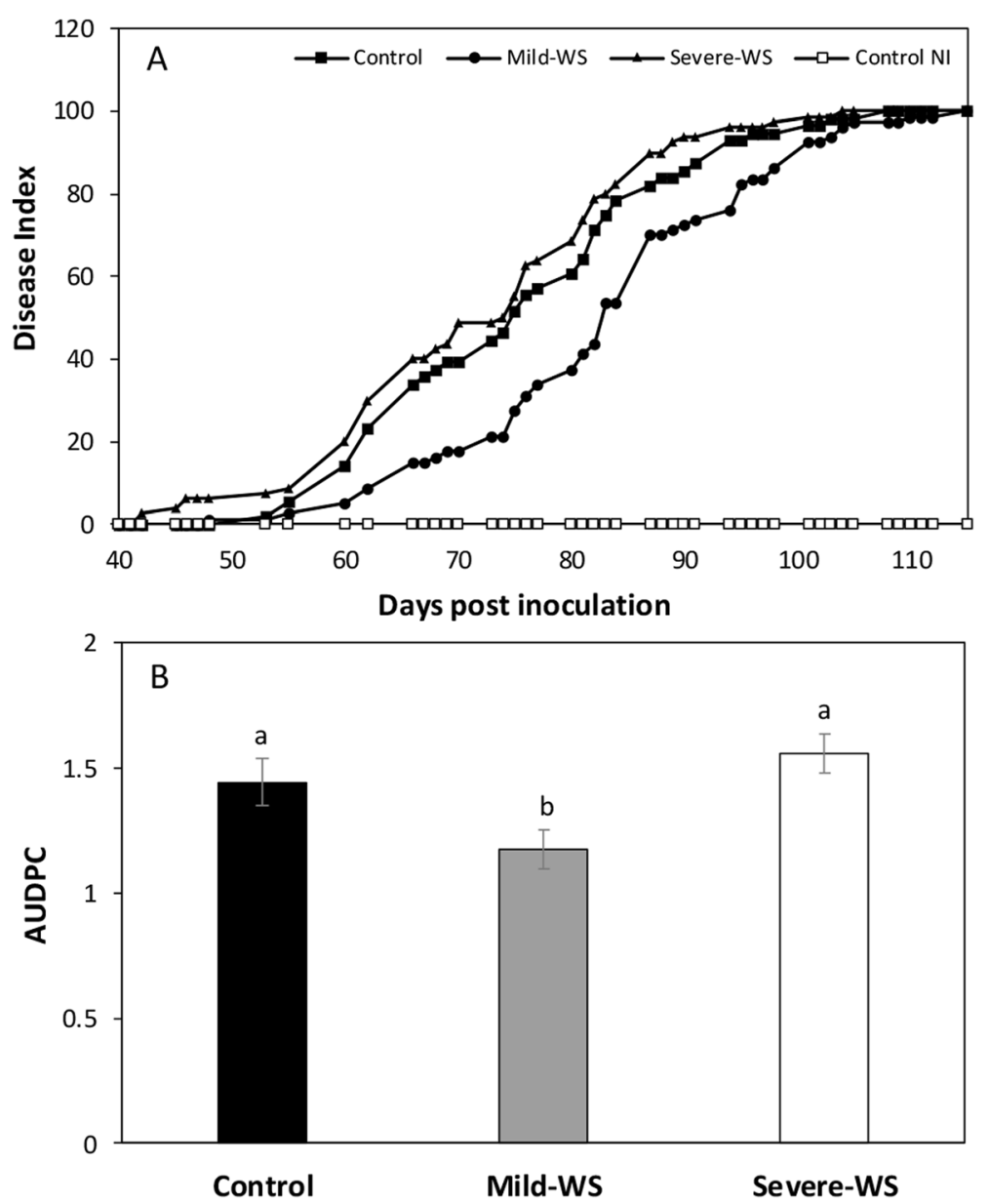

Fig. 5 Disease index calculated by evaluating aerial symptoms in control, mild-WS and severe-WS primed 'Dusa' plants infected with R. necatrix $(\mathbf{a})$, and mean values $( \pm \mathrm{SE}$, controls $n=18$ and treatments $n=20)$ of area under disease progress curve (AUDPC) for each treatment $(\mathbf{b})$. Different letters indicate significant differences among groups $(P<0.05$; one-way ANOVA followed by LSD)

and severe water stress in other woody plants $[71,72]$ and in avocado trees [73, 74]. 'Dusa' rootstock response to either $R$. necatrix infection or water stress treatments displayed water potential and $g_{\mathrm{s}}$ values that dropped below $1.0 \mathrm{MPa}$ and $0.05 \mathrm{~mol} \mathrm{~m}^{-2} \mathrm{~s}^{-1}$, respectively, suggesting an oxidative burst in photosynthetic tissues $[75,76]$. This agrees with the higher NPQ and $q \mathrm{~N}$ values $[77,78]$ and with a potential vulnerability to cavitation that could limit water flow from roots towards the upperparts of the trees, especially in severe-WS $[79,80]$. In the $R$. necatrix/avocado interaction, this limitation of water flow is consistent with the profuse invasion of root vascular system during pathogen root colonization [70, 81].

Molecular responses at the root level showed the upregulation of six out of the thirteen tested genes under both water stress treatments (Table 2). These genes, besides being involved in the avocado response to soilborne pathogens ( $P$. cinnamomi and $R$. necatrix), are also induced in the response of other horticultural and woody species (i.e. Citrus spp., Malus domestica, Populus trichocarpa) to water deficit [45, 82-86]. It is remarkable the increased overexpression of NAC transcription factor accordingly to the intensity of the water stress level, which could be supporting a major accumulation of ROS species under severe-WS since, among other functions, this gene has been associated with the up-regulation of ROS-scavenging genes under abiotic stresses [61]. On the other hand, mild-WS repressed seven out of the thirteen genes, three of which remained down-regulated in the severe-WS (Table 2). NPR1 and PR5 repression is in consonance with the ABA biosynthesis and signalling induced under water stress [87], known to exert an antagonistic effect on the salicylic acid (SA) pathway [88] in which NPR1 functions as a master regulator inducing the expression of pathogenesis related proteins (PR) such as PR5 $[89,90]$, which are potentially involved in the maintenance of osmotic adjustment in cells [65].

The results stated above indicate that pathways involved in the avocado response to gradually imposed water stress lead to the induction of genes expressed in incompatible interactions against fungal pathogens $[43$, 
90]. In this regard, co-occurrence of water stress and soilborne pathogens could have a positive effect in achieving tolerance against the pathogen (i.e. crosstolerance, $[20,21])$ or a negative additive effect, making plants more susceptible [16, 91-94]. Additional studies on avocado are required to clarify this point.

Previous studies have suggested the use of 'priming' [10-12] with drought stress to achieve tolerance to forthcoming diseases [16]. This acquired tolerance is based on sustained changes on the basal levels of cellular and molecular defense in primed plants after cessation of stimuli compared to non-primed ones [11, 12, 16]. In the present study, water status and photosynthetic performance was completely restored in drought-primed plants one week after re-watering regardless of the predrought intensity. This fast recovery suggests that impairment of whole plant transpirational flow and photosynthesis did not lead to irreversible changes on avocado and can be indicative of some degree of drought adaptation [78].

However, at the root level, re-watering induced the upregulation of defense related genes, suggesting a 'primed state' of the previously water stressed avocado plants. Gene overexpression, which could be associated with crosstalk between the different signaling pathways underlying plant tolerance/resistance to biotic and abiotic stress such as the abscisic (ABA), jasmonic (JA) and salicylic (SA) acids [95-98], was more remarkable in mild-WS compared to severe-WS. Particularly, the induction of NPR1 transcription factor in mild-WS primed plants suggests the activation of salicylic acid-mediated defense responses [52, 89, 90] and the deactivation of ABA-related responses after water stress [99]. In addition, this 'primed state' is accompanied by the significant accumulation of PR proteins (i.e. PR4 and PR5) which have been correlated with the development of systemic acquired resistance [48] and are considered the most promising candidates for developing multiple stress tolerance [89]. It is also remarkable that the expression of genes related with fungal cell wall degradation, such as endochitinase, was only up-regulated in plants recovered after mild-WS. Genes encoding metallothionein, universal stress protein, protease inhibitor and NAC domain containing protein 72 remained overexpressed in mild-WS primed plants. These genes are involved in the general plant response to stress $[51,58,60,62$, $64,67,82,100-103]$, playing the last two a fundamental role in avocado defense to $R$. necatrix [43]. It should be highlighted the marked overexpression of the gene encoding the NAC domain containing protein 72 (24 fold over mild-WS) in roots recovered from mild-WS compared to severe-WS, suggesting a higher promotion of root development [104, 105], although further studies are necessary to clarify its importance on the water stress recovery response.

The performed pathogenicity test shed light on whether this water-stress induced 'primed state' was effective for enhancing avocado tolerance to this necrotrophic pathogen. In this sense, the disease progression delay, observed in mild-WS primed plants in comparison with control and severe-WS primed plants, suggests an enhancement of plant ability to cope with $R$. necatrix infection after priming with mild water stress. This ability could be attributable to differential expression of key genes involved in the tolerance of avocado to soilborne pathogens such as NPR1 and NAC domain containing protein 72 , as well as with a lower energy investment for overcoming a moderate water stress compared with severely stressed plants [72]. Moreover, although all of the overexpressed genes in mild-WS primed plants are involved in plant defense against fungi, not all have been described to be related with avocado tolerance to $R$. necatrix (i.e. NPR1, PR4, PR5 and endochitinase). However, their enhanced expression after drought-priming (i.e. abiotic factor) could also represent a benefit for avocado plants to overcome forthcoming fungal infection (i.e. biotic stressor).

\section{Conclusions}

In conclusion, this is the first study reporting the effectiveness of 'cross-factor priming' on the susceptible avocado rootstock 'Dusa' for increasing its tolerance to white root rot disease. Mild-WS induced a primed state in the WRR susceptible avocado rootstock 'Dusa' by overexpressing fungal defense related genes, revealing that plant responses against biotic and abiotic stress rely on common mechanisms. Although future experiments must be carried out on grafted plants, results presented here indicate the possibility of using moderate water stress as an approach to reduce $R$. necatrix impact on avocado orchards infected with the pathogen. These results reinforce the use of deficit irrigation strategies for disease management and water savings in cropping areas with limited water resources [74].

\section{Methods}

\section{Plant material and experimental design}

In order to test if water stress can be used as a priming factor for improving avocado tolerance to $R$. necatrix, a 'cross-factor priming' experiment was carried out in 2017 at the Institute of Agricultural Research and Training (IFAPA) (Málaga, south-eastern Spain, 36 40' 25" N, $04^{\circ} 30^{\prime} 11^{\prime \prime} \mathrm{W}$, elevation of $32 \mathrm{~m}$ below sea level). One hundred and twelve 2-year old clonal 'Dusa' plants (Westfalia Estate, South Africa) propagated by Brokaw nursery (Brokaw España S.L.) using a modified Frohlich method [106], were grown in $16 \mathrm{~L}$ pots containing a 
sterilised mixture of organic substrate and sand supplemented with a slow-release fertiliser (Basacote Plus $6 \mathrm{M}$, Compo Expert $\mathrm{GmbH}$ ).

'Dusa' plants were kept in a greenhouse under day light illumination and semi-controlled conditions of air temperature (T) and relative humidity (RH). Photosynthetic photon flux density (PPFD), $\mathrm{T}$ and $\mathrm{RH}$ conditions inside the greenhouse were continuously registered by a quantum sensor (Apogee SQ-110, USA) and by a T/RH U23-001 $\mathrm{HOBO}^{\circ}$ Pro v2 logger (Onset Computer Corporation, USA). Maximal midday values of PPFD varied between 440 and $1012 \mu \mathrm{mol} \mathrm{m}^{-2} \mathrm{~s}^{-1}$, and daily $\mathrm{T}$ was allowed to fluctuate according to external weather conditions, but its variation range inside the greenhouse was maintained between $20 \pm 10^{\circ} \mathrm{C}$ by an automatic cooling system and heating when necessary. The $\mathrm{RH}$ values inside the greenhouse were always over $40 \%$.

The experimental design is depicted in Fig. 1. At the beginning of the experiment $\left(t_{0}\right)$, plant physiological status was tested non-destructively by measuring chlorophyll fluorescence at predawn. Plants were randomly distributed in rows into two sets of 56 plants to conduct two trials. For each trial, 18 plants were randomly assigned to a control group, in which soil moisture was maintained at field capacity (Fc) throughout the experimentation, and two sets of 19 plants were subjected to controlled substrate dryingup until they reached $50 \%$ of Fc (i.e. mild water stress, mild-WS) and $25 \%$ of Fc (i.e. severe water stress, severe-WS), respectively. Once these soil water content levels were attained (after $\sim 16-17$ days; $t_{1}$ ), full irrigation was restored in all plants and drought recovery response was assessed one week after rewatering (i.e. after $\sim 23-24$ days; $t_{2}$ ). Hereinafter, the term 'primed plants' refers to plants subjected to each of the water stress levels followed by a recovery period. The pathogenicity test with $R$. necatrix was performed at $t_{2}$ as described below.

Soil moisture was monitored in all plants with a wet sensor (HH2 Moisture meter, Delta-T Devices. Cambridge, England), previously calibrated for the substrate, which also allowed adjustment of volumetric soil moisture $(\mathrm{v} / \mathrm{v})$ for each water treatment (mild-WS and severe-WS) in relation to the soil water holding at field capacity $(\mathrm{Fc} \sim 0.4 \mathrm{v} / \mathrm{v})$. Once per week plants were fertilised with an NPK solution (Kristalon Blue 17-6-18, Yara, UK) supplemented with iron chelate (Sequestrene, Syngenta, Spain).

Throughout the experiment, physiological measurements and root samplings were carried out at $t_{1}$ and $t_{2}$. On each trial, 15 plants per treatment were measured at each sampling point. Roots were sampled from 9 plants per treatment not used for the pathogenicity test.

\section{Physiological measurements}

Midday (12:00-14:00 am) leaf water potential was measured at $t_{1}$ (when mild-WS and severe-WS plants reached 50 and $25 \%$ of $\mathrm{Fc}$ ) and at $\mathrm{t}_{2}$ (one week after rewatering) using a Schölander pressure chamber (model 3005; Soil Moisture Equipment Corporation, Santa Barbara, CA, USA). On each trial, 15 plants per treatment were measured at each sampling point. Measurements were done in one mature fully developed leaf per plant close to the main stem. After cutting, leaves were immediately placed in the chamber following the recommendations made by Hsiao [107].

Relative leaf water content (RWC), the specific leaf mass area (LMA) and relative chlorophyll content (SPAD index) were measured only at $t_{1}$ in the same plants as for leaf water potential determinations. For RWC determinations, leaf discs $\left(2 \mathrm{~cm}^{2}\right)$ were sampled at midday, weighed to obtain fresh weight $\left(\mathrm{F}_{\mathrm{W}}\right)$ and immediately imbibed on distilled water for $24 \mathrm{~h}$ at $5{ }^{\circ} \mathrm{C}$ in darkness for obtaining turgid weight $\left(\mathrm{T}_{\mathrm{W}}\right)$. Afterwards, samples were oven dried at $80^{\circ} \mathrm{C}$ for $48 \mathrm{~h}$ to get dry weight $\left(D_{W}\right)$. RWC was calculated as follows:

$$
\operatorname{RWC}(\%)=\left[\left(F_{W}-D_{W}\right) /\left(T_{W}-D_{W}\right)\right] \times 100
$$

The specific leaf mass area (LMA) was calculated as the ratio between disc dry weight and disc area $\left(\mathrm{g} \mathrm{cm}^{-2}\right)$.

The SPAD index was non-destructively measured at midday on one leaf per plant using a hand-held SPAD $502 \mathrm{~m}$ (Minolta, Osaka, Japan). This index provides an estimation of leaf chlorophyll content consistent with leaf greenness [108]. For each plant, averaged SPAD values were calculated from three readings per leaf.

In vivo chlorophyll $a$ fluorescence signals were measured with a portable fluorometer PAM-2100 (Heinz Walz, Effeltrich, Germany) at predawn (at $\mathrm{t}_{0}$ ) and midday (at $t_{1}$ and $t_{2}$ ) in one leaf per plant. The so-called saturation pulse method was used to determine all fluorescence parameters [109]. Dark-adapted parameters (i.e. minimal fluorescence $\left(F_{0}\right)$, maximal fluorescence $\left(F_{\mathrm{m}}\right)$ and maximal photochemical efficiency of PSII $\left(F_{\mathrm{v}} / F_{\mathrm{m}}=\left[F_{\mathrm{m}}-F_{0}\right] / F_{\mathrm{m}}\right)$ were determined at predawn $(05: 00-07: 00 \mathrm{am})$. The steady-state fluorescence $\left(F_{\mathrm{t}}\right)$, maximal fluorescence $\left(F_{\mathrm{m}}{ }^{\prime}\right)$ and minimal fluorescence yield of a pre-illuminated sample $\left(F_{0}{ }^{\prime}\right)$ were assessed in light acclimated leaves $(\sim 450 \mu \mathrm{mol}$ quanta $\left.\mathrm{m}^{-2} \mathrm{~s}^{-1}\right)$. The relative quantum yield of PSII photochemistry $\left(\right.$ PPSII $\left.=\left[F_{\mathrm{m}}{ }^{\prime}-F_{\mathrm{t}}\right] / F_{\mathrm{m}}{ }^{\prime}\right)[110]$, the fraction of PSII centres in open state $(q \mathrm{~L})$ [47] and the extent of "Stern-Volmer" non-photo-chemical fluorescence quenching $\left(\mathrm{NPQ}=\left[F_{\mathrm{m}}-F_{\mathrm{m}}{ }^{\prime}\right] /\left[F_{\mathrm{m}}{ }^{\prime}\right]\right)[111]$ were calculated.

Leaf gas exchange was measured at midday (11:0014:00 am) at $t_{1}$ and $t_{2}$ in one mature exposed leaf. Measurements were performed with an open portable 
photosynthesis system (model LI-6400, LI-COR, USA) equipped with a LED-light source (6400-02B), coupled to a sensor head/IRGA, and with a $\mathrm{CO}_{2}$ mixer (6400-01) to modify the incoming air's $\mathrm{CO}_{2}$ concentrations. The operating flow rate was $500 \mathrm{~mL}$ $\mathrm{min}^{-1}$ and $\mathrm{CO}_{2}$ partial pressure was $400 \mathrm{ppm}$. Saturating photosynthetic photon flux density $(1000 \mu \mathrm{mol}$ $\mathrm{m}^{-2} \mathrm{~s}^{-1}$ ) was chosen as the default condition. Leaf temperature was kept at $\sim 20^{\circ} \mathrm{C}$ and relative humidity was adjusted to $50 \%$ (vapor pressure deficit $\sim 1.4 \mathrm{kPa}$ ). Net $\mathrm{CO}_{2}$ assimilation rates $\left(A_{\mathrm{N}}\right)$ and stomatal conductance $\left(g_{\mathrm{s}}\right)$ were estimated with the equations of Von Caemmerer and Farquhar [112].

\section{RNA extraction}

Roots from 9 avocado plants from control, mild-WS and severe-WS were harvested at $t_{1}$ and $t_{2}$ in plants others than those used in the pathogenicity test. Three biological replicates were used for RNA extraction. Each replicate consisted in a bulk sample from three plants. RNA from ground root tissue was extracted using the CTAB extraction method [113], a simple and efficient method for isolating RNA from pine trees with slight modification. The chloroform:isoamyl alcohol step was repeated 3-5 times, depending on the stability of the interphase and colour of the sample. RNA quantity and quality were determined based on A260/280 and A260/ 230 wavelength ratios using a NanoDrop ${ }^{\circ}$ ND-1000 (Nanodrop Technologies, Inc., Montchanin, USA) spectrophotometer. RNA integrity was confirmed by the appearance of ribosomal RNA bands and lack of degradation products after separation on a $2 \%$ agarose gel and Red Safe staining. DNase treatment of RNA was performed by the addition of $1 \mathrm{U}$ RNase-free DNase (Thermo Scientific, Life Technologies Inc., Carlsbad, California, USA), $1 \mu \mathrm{L}$ 10x reaction buffer with $\mathrm{MgCl}_{2}, 1 \mu \mathrm{g}$ RNA, $0.5 \mu \mathrm{L}$ of RiboLock RNase Inhibitor (Thermo Scientific Inc., California, USA) and diethylpyrocarbonate-treated water to a final volume of $10 \mu \mathrm{L}$. The mixture was incubated at $37^{\circ} \mathrm{C}$ for $45 \mathrm{~min}$ followed by the addition $1 \mu \mathrm{L}$ of $50 \mathrm{mM}$ EDTA and incubation at $65^{\circ} \mathrm{C}$ for $10 \mathrm{~min}$.

\section{Quantitative real-time PCR}

Single stranded cDNA was synthesized using iScript Reverse Transcription Supermix (Bio-Rad Laboratories Inc., California, USA) according to manufacturer's instructions. The cDNA was analysed for genomic DNA contamination by PCR using gene specific primers F3H-F (5'-TCTGATTT CGGAGATGACTCGC-3') and F3H-R (5'-TGTAG ACTTGGGCCACCTCTTT-3'), which flank an intron of the eflavone 3-hydroxylase (F3H) gene. PCR amplifications were carried out as previously described by Engelbrecht and van den Berg [48] using first-strand cDNA as the template.
The expression of thirteen avocado genes was investigated based on previous literature. The actin gene was used as endogenous control for normalization. Primer sequences for endogenous control gene and the thirteen avocado genes are presented in Additional file 1: Table S1. Primer pairs were chosen to generate fragments between 70 to $140 \mathrm{bp}$ and were designed using Primer 3 software (http://bioinfo.ut.ee/primer3-0.4.0/, [114, 115]). Primer specificity was tested by first performing a conventional PCR and confirmed by the presence of a single melting curve during qRT-PCR. Serial dilutions $(1: 10,1: 20,1: 50,1: 200)$ were made from a pool of cDNA from each treatment and time-points, and calibration curves were performed for each gene. For qRT-PCR, the reaction mixture consisted of cDNA first-strand template, primers $(500 \mathrm{nmol}$ final concentration) and SYBR Green Master Mix (SsoAdvanced Universal SYBR Green Supermix, Bio-Rad) in a total volume of $20 \mu \mathrm{l}$. The PCR conditions were as follows: $30 \mathrm{~s}$ at $95^{\circ} \mathrm{C}$, followed by 40 cycles of $15 \mathrm{~s}$ at $95^{\circ} \mathrm{C}$ and $30 \mathrm{~s}$ at $60{ }^{\circ} \mathrm{C}, 3 \mathrm{~min}$ at $72{ }^{\circ} \mathrm{C}, 1 \mathrm{~min}$ at $95^{\circ} \mathrm{C}$. The reactions were performed using an $\mathrm{iQ} 5$ real-time PCR detection system (Bio-Rad). Relative quantification of the expression levels for the target was analysed using the $\Delta \Delta \mathrm{Ct}$ method [116]. All reactions were done in triplicate.

\section{Pathogenicity test in avocado plants}

Inoculum was produced on wheat seeds according to Sztejnberg and Madar [117]. Briefly, seeds were soaked for $12 \mathrm{~h}$ in $250 \mathrm{ml}$ Erlenmeyer flasks filled with distilled water. The flasks, each containing $100 \mathrm{~g}$ of seeds, were subsequently autoclaved after excess water drained off. After sterilisation, four $0.5 \mathrm{~cm}$ diameter fungal discs of a 2-week-old culture of $R$. necatrix grown on potato dextrose agar (PDA) were placed aseptically in each flask and incubated at $24{ }^{\circ} \mathrm{C}$ in the dark for three weeks until wheat grains were homogeneously covered by $R$. necatrix mycelium. Seven days after re-watering $\left(t_{2}\right)$, 'Dusa' rootstocks from each treatment (control $n=9$, mild-WS $n=10$, severe-WS $\mathrm{n}=10$ ) on each of the two trials, were inoculated with $3.75 \mathrm{~g}$ of colonized wheat seeds per litter of substrate. To ensure the spread of the inoculum, it was placed at eight points scattered around the stem $(\sim 3.5 \mathrm{~cm}$ apart) and introduced at two depths $(\sim 5 \mathrm{~cm}$ and $\sim 15$ $\mathrm{cm}$, respectively). Disease progression was evaluated by measuring the aerial symptoms of WRR according to a scale: $1=$ healthy plant; $2=$ mild wilting; $3=$ wilting; 4 =desiccated; and $5=$ death. The disease index (DI) for each treatment and the area under the disease progress curve (AUDPC) was calculated as previously described by Teixeira de Sousa [118] and Campbell and Madden [119], respectively. 


\section{Statistical analysis}

Data were analysed using the analytical software STATISTICA 7 (StatSoft, Inc., USA). Differences among treatments in physiological variables and AUDPC were evaluated by analysis of variance (ANOVA). On each sampling point, datasets obtained from the two trials were subjected to a two-way ANOVA, in which 'trial' and 'treatment' were the between-subjects factors. This analysis allowed to test whether the variability observed between the two trials was significantly different or not, and to what extent was it possible to merge datasets for performing a unique one-way ANOVA for each sampling point. Since no significant effect of 'trial' was observed in any of the variables analysed, data from the two trials were analysed jointly. Therefore, data depicted in the figures for each treatment are average values of the measurements taken in the two trials. Significant differences were considered at the $5 \%$ probability level unless otherwise stated. Prior to ANOVA, normality and homogeneity assumptions were tested by using the Kolmogorov-Smirnov and the Cochran's $\mathrm{C}$ test, respectively. When significant differences were found, Fisher's least significant difference (LSD) test was used to compare mean values. Statistical analysis of qRT-PCR data was carried out by Student's t-test with Sigma Stat version 4.0 software (Systat Software GmbH).

\section{Additional file}

Additional file 1: Table S1. Primers used in the GRT-PCR experiments. (DOC $67 \mathrm{~kb}$ )

\begin{abstract}
Abbreviations
ABA: Abscisic acid; $A_{N}$ : net $\mathrm{CO}_{2}$ assimilation rates; AUDPC: area under disease progress curve; Dl: disease index; Dw: dry weight; Fc: Field capacity; FC: Fold change; $F_{\mathrm{v}} / F_{\mathrm{m}}$ : Maximal photochemical efficiency of $\mathrm{PSII} ; F_{\mathrm{v}}{ }^{\prime} / F_{\mathrm{m}}$ ': maximum photochemical efficiency of the open reaction centres of PSIl; $F_{W}$ : Fresh weight; $g_{s}$ : stomatal conductance; JA: Jasmonic acid; LMA: Leaf mass area; NPQ: Non-photochemical quenching of fluorescence; NPR: Non-expressor of pathogenesis related; PDA: Potato dextrose agar; PPFD: Photosynthetic photon flux density; PR: Pathogenesis-related; PRR: Phytophthora root rot; PSII: Photosystem II; qL: Fraction of PSII centres in open state; qN: Coefficient of non-photochemical quenching; qRT-PCR: real time quantitative PCR; RH: Relative humidity; ROS: Reactive oxygen species; RWC: Relative water content; SA: Salicylic acid; T: Temperature; Tm: Primer melting temperature; Tw: Turgid weight; WRR: White root rot; WS: Water stress; $\phi$ PSII: Relative quantum yield of PSII photochemistry
\end{abstract}

\section{Acknowledgements}

Authors would like to thank Mrs. J. Engelbrecht, Dr. A. Zumaquero and Dr. F. Pliego for their support at the laboratory and valuable comments to experimental design.

\section{Authors' contributions}

$\mathrm{CP}$ and EMF planed and designed the experiment and obtained the fundings. CP, EMF, GMO and NB conducted the experiments, collected and analysed the data. CP, EMF and GMO prepared the draft. All authors wrote, reviewed and edited the manuscript.

\section{Authors' information}

G. Moreno-Ortega is a graduate student at the Ph.D. Program of Advance Biotechnology, University of Málaga.

\section{Funding}

This research was supported by the RTA2017-00040-00-00 (INIA-AEI), AVA201601.14 and AVA2019.008 projects (20\% Junta de Andalucía, 80\% FEDER). The funding bodies had no role in the design of the study and no role in the collection, analysis, and interpretation of data or in writing the manuscript. C Pliego is currently supported by an INIA-CCAA contract, cofinanced by INIA (20\%) and FEDER (80\%).

\section{Availability of data and materials}

All data generated or analysed during this study are included in this published article [and its supplementary information files].

\section{Ethics approval and consent to participate}

The acquisition, cultivation, and testing of plant materials, carried out in this study, followed national and local legislation.

\section{Consent for publication}

"Not Applicable".

\section{Competing interests}

"Not Applicable".

\section{Author details}

${ }^{1}$ IFAPA. Centro de Málaga. Cortijo de la Cruz s/n, 29140 Churriana, Málaga, Spain. ${ }^{2}$ Department of Biochemistry, Genetics and Microbiology, University of Pretoria, Pretoria, South Africa. ${ }^{3}$ Forestry and Agricultural Biotechnology Institute (FABI), University of Pretoria, Pretoria, South Africa.

Received: 5 July 2019 Accepted: 3 September 2019

Published online: 29 October 2019

\section{References}

1. Nordqvist C. What are the top healthful foods? Medical news today. MediLexicon, Intl. 20 Jun. 2017. Web.. https:/www.medicalnewstoday.com/ articles/245259.php.

2. World Avocado Organization (WAO). 2019. https://avocadofruitoflife.com/ retail. Accessed 19 June 2019.

3. FAOSTAT. Fao.org. 2018. http://www.fao.org/faostat/en/. Accessed $18 \mathrm{mar}$ 2019.

4. Pérez-Jiménez RM. Significant avocado diseases caused by fungi and oomycetes. Eur J Plant Sci Biotechnol. 2008;2(1):1-24.

5. Coffey MD. Phytophthora root rot of avocado: an integrated approach to control in California. Plant Dis. 1987;71:1046-52.

6. Giblin F, Pegg K, Willingham S, Anderson J, Coates L, Cooke T, et al. Phytophthora revisited. Proc. of the New Zealand and Australia Avocado Grower's Conference, Tauranga, New Zealand. Avocado Growers Association: In; 2005. http://www.avocadosource.com/Journals/AUSNZ/ AUSNZ_2005/GiblinFiona2005.pdf.

7. Freeman S, Sztejnberg A. Rosellinia. In: Singleton L, Mihail D, Rush M, editors. Methods for Research on Soilborne Phytopathogenic. St. Paul, Minnesota. USA: APS PRESS; 1992. p71-p73.

8. Pliego C, López-Herrera C, Ramos C, Cazorla FM. Developing tools to unravel the biological secrets of Rosellinia necatrix, an emergent threat to woody crops. Mol Plant Pathol. 2012;13(3):226-39.

9. Barceló-Muñoz A, Zea-Bonilla T, Jurado-Valle I, Imbroda-Solano I, Vidoy-Mercado I, Pliego-Alfaro F, et al. Programa de selección de portainjertos de aguacate tolerantes a la podredumbre blanca causada por Rosellinia necatrix en el Sur de España 2007. www.avocadosource.com/WAC5/Papers/WAC5_p537.pdf.

10. Conrath U, Beckers GJ, Flors V, García-Agustín P, Jakab G, Mauch F, et al. Priming: getting ready for battle. Mol Plant-Microbe Interact. 2006;19(10): 1062-71.

11. Bruce TJA, Mathers MC, Napier JA, Pickett JA. Stressful memories of plants: evidence and possible mechanisms. Plant Sci. 2007;173(6):603-8.

12. Pastor V, Balmer A, Gamir J, Flors V, Mauch-Mani B. Preparing to fight back: generation and storage of priming compounds. Front Plant Sci. 2014;5:1-12.

13. Conrath U. Molecular aspects of defence priming. Trends Plant Sci. 2011, 16(10):524-31. 
14. Wang X, Vignjevic M, Juang D, Jacobsen S, Wollenweber B. Improved tolerance to drought stress after anthesis due to priming before anthesis in wheat (Triticum aestivum L.) var. Vinjett. J Exp Bot. 2014;65(22):6441-56.

15. Molassiotis A, Tanou G, Diamantidis G. No says more than 'YES' to salt tolerance. Salt priming and systemic nitric oxide signaling in plants. Plant Signal Behav. 2010;5(3):209-12.

16. Barradas C, Pinto G, Correia B, Castro B, Phillips AJ, Alves A. Drought x disease interaction in Eucalyptus globulus under Neofusicoccum eucalyptorum infection. Plant Pathol. 2018;67:87-96.

17. Pastor V, Luna E, Mauch-Mani B, Ton J, Flors V. Primed plants do not forget. Environ Exp Bot. 2013;94:46-56

18. Munné-Bosch S, Peñuelas J. Photo- and antioxidative protection, and a role for salicylic acid during drought and recovery in field grown Phillyrea angustifolia plants. Planta. 2003;217(5):758-66.

19. van den Berg N, Mahomed W, Olivier NA, Swart V, Crampton BG. Transcriptome analysis of an incompatible Persea americana-Phytophthora cinnamomi interaction reveals the involvement of SA- and JA-pathways in a successful defense response. PLoS One. 2018;13(10):e0205705.

20. Ramegowda V, Senthil-Kumar M, Ishiga Y, Kaundal A, Udayakumar M, Mysore KS. Drought stress acclimation imparts tolerance to Sclerotinia sclerotiorum and Pseudomonas syringae in Nicotiana benthamiana. Int J Mol Sci. 2013;14(5):9497-513.

21. Rejeb IB, Pastor $V$, Mauch-Mani B. Plant responses to simultaneous biotic and abiotic stress: molecular mechanisms. Plants (Basel). 2014;3(4):458-75.

22. Hayat S, Ahmad A. Salicylic acid: a plant hormone. Springer, Dordrecht: Springer; 2007.

23. Rivas-San Vicente M, Plasencia J. Salicylic acid beyond defence: its role in plant growth and development. J Exp Bot. 2011;62(10):3321-38.

24. Singh B, Usha K. Salicylic acid induced physiological and biochemical changes in wheat seedlings under water stress. Plant Growth Regul. 2003;39(2):137-41.

25. Chini A, Grant JJ, Seki M, Shinozaki K, Loake GJ. Drought tolerance established by enhanced expression of the CCI-NBS-LRR gene, ADR1, requires salicylic acid, EDS1 and ABI1. Plant J. 2014;38(5):810-22.

26. Miura K, Tada Y. Regulation of water, salinity, and cold stress responses by salicylic acid. Front Plant Sci. 2014;5:4.

27. Durner J, Shah J, Klessig DF. Salicylic acid and disease resistance in plants. Trends Plant Sci. 1997;2(7):266-74.

28. Dempsey DA, Shah J, Klessig DF. Salicylic acid and disease resistance in plants. CRC Crit Rev Plant Sci. 1999;18(4):547-75.

29. Chaturvedi R, Shah J. Salicylic acid in plant disease resistance. In: Hayat S, Ahmad A, editors. Salicylic acid: a plant hormone. Dordrecht: Springer; 2007. p. 335-70.

30. Kumar D. Salicylic acid signaling in disease resistance. Plant Sci. 2014;228: 127-34.

31. Cao H, Bowling SA, Gordon AS, Dong X. Characterization of an Arabidopsis mutant that is non-responsive to inducers of systemic acquired resistance. Plant Cell. 1994;6(11):1583-92.

32. Delaney TP, Friedrich L, Ryals JA. Arabidopsis signal transduction mutant defective in chemically and biologically induced disease resistance. Proc Natl Acad Sci U S A. 1995;92(14):6602-6

33. Okushima Y, Koizumi N, Kusano T, Sano H. Secreted proteins of tobacco cultured BY2 cells: identification of a new member of pathogenesis-related proteins. Plant Mol Biol. 2000;42(3):479-88.

34. Park CJ, Kim KJ, Shin R, Park JM, Shin YC, Paek KH. Pathogenesis-related protein 10 isolated from hot pepper functions as a ribonuclease in an antiviral pathway. Plant J. 2004;37(2):186-98.

35. Ceasar SA, Ignacimuthu S. Genetic engineering of crop plants for fungal resistance: role of antifungal genes. Biotechnol Lett. 2012;34(6):995-1002.

36. Jiang L, Wu J, Fan S, Li W, Dong L, Cheng Q. Isolation and characterization of a novel pathogenesis-related protein gene (GmPRP) with induced expression in soybean (Glycine max) during infection with Phytophthora sojae. PLoS One. 2015;10(6):e0129932.

37. Dai L, Wang D, Xie X, Zhang C, Wang X, Xu Y, et al. The novel gene VpPR41 from Vitis pseudoreticulata increases powdery mildew resistance in transgenic Vitis vinifera L. Front Plant Sci. 2016;7:695.

38. Seo PJ, Lee AK, Xiang F, Park CM. Molecular and functional profiling of Arabidopsis pathogenesis-related genes: insights into their roles in salt response of seed germination. Plant Cell Physiol. 2008;49(3):334-44.

39. Tsutsui T, Kato W, Asada Y. DEAR1, a transcriptional repressor of DREB protein that mediates plant defense and freezing stress responses in Arabidopsis. J Plant Res. 2009;122(6):633-43.
40. Janska A, Marsik P, Zelenkova S, Ovesna J. Cold stress and acclimation: what is important for metabolic adjustment? Plant Biol (Stuttg). 2010; 12(3):395-405.

41. Singh NK, Kumar KRR, Kumar D, Shukla P, Kirti PB. Characterization of a pathogen induced thaumatin-like protein gene AdTLP from Arachis diogoi, a wild peanut. PLoS One. 2013;8(12):e83963.

42. Ali S, Mir ZA, Tyagi A, Bhat JA, Chandrashekar N, Papolu PK, et al. Identification and comparative analysis of Brassica juncea pathogenesisrelated genes in response to hormonal, biotic and abiotic stresses. Acta Physiol Plant. 2017;39:1-15.

43. Zumaquero A, Martínez-Ferri E, Matas AJ, Reeksting B, Olivier NA, PliegoAlfaro $F$, et al. Rosellinia necatrix infection induces differential gene expression between tolerant and susceptible avocado rootstocks. PLoS One. 2019;14(2):e0212359

44. Lee B, Jung W, Lee B, Avice J, Ourry A, Kim T. Kinetics of drought-induced pathogenesis-related proteins and its physiological significance in white clover leaves. Physiol Plant. 2008;132(3):329-37.

45. Srinivasan T, Kirti PB. Protease inhibitors and stress tolerance. Funct Plant Sci Biotechnol. 2012;6(1):59-66.

46. Borges AA, Jiménez-Arias D, Expósito-Rodríguez M, Sandalio LM, Pérez JA. Priming crops against biotic and abiotic stresses: MSB as a tool for studying mechanisms. Front Plant Sci. 2014;5:642

47. Baker NR, Harbinson J, Kramer DM. Determining the limitations and regulation of photosynthetic energy transduction in leaves. Plant Cell Environ. 2007;30(9):1107-25.

48. Engelbrecht J, van den Berg N. Expression of defence-related genes against Phytophthora cinnamomi in five avocado rootstocks. S Afr J Sci. 2013; 109(11-12).

49. Reeksting BJ, Taylor N, van den Berg N. Flooding and Phytophthora cinnamomi: Effects on photosynthesis and chlorophyll fluorescence in shoots of non-grafted Persea americana (Mill.) rootstocks differing in tolerance to Phytophthora root rot. S Afr J Bot. 2014:95:40-53.

50. Reeksting BJ, Olivier NA, van den Berg N. Transcriptome responses of an ungrafted Phytophthora root rot tolerant avocado (Persea americana) rootstock to flooding and Phytophthora cinnamomi. BMC Plant Biol. 2016; 16(1):205.

51. Mahomed W, van den Berg N. EST sequencing and gene expression profiling of defence-related genes from Persea americana infected with Phytophthora cinnamomi. BMC Plant Biol. 2011;11:167.

52. Backer R, Mahomed W, Reeksting BJ, Engelbrecht J, Ibarra-Laclette E, van den Berg N. Phylogenetic and expression analysis of the NPR1-like gene family from Persea americana (Mill.). Front Plant Sci. 2015;6:300.

53. Xia Y, Suzuki H, Borevitz J, Blount J, Guo Z, Patel K, et al. An extracellular aspartic protease functions in Arabidopsis disease resistance signalling EMBO J. 2004:23(4):980-8.

54. Guo M, Liu X, Wang J, Li L, Zhang W, Gong B, et al. Investigation on saltresponse mechanisms in Arabidopsis thaliana from UniProt protein knowledgebase. J Plant Interact. 2019;14(1):21-9.

55. de las Mercedes Dana M, Pintor-Toro JA, Cubero B. Transgenic tobacco plants overexpressing chitinases of fungal origin show enhanced resistance to biotic and abiotic stress agents. Plant Physiol 2006:142(2):722-730.

56. Kumar S, Trivedi PK. Glutathione S-transferases: role in combating abiotic stresses including arsenic detoxification in plants. Front Plant Sci. 2018;9:751.

57. Rodrigues FA, de Laia ML, Zingaretti SM. Analysis of gene expression profiles under water stress in tolerant and sensitive sugarcane plants. Plant Sci. 2008;176(2):286-302.

58. Cruz de Carvalho MH. Drought stress and reactive oxygen species: production, scavenging and signaling. Plant Signal Behav. 2008;3(3):156-65.

59. Xiao JP, Zhang LL, Zhang HQ, Miao LX. Identification of genes involved in the responses of tangor (C. reticulata $\times$ C. sinensis) to drought stress. Biomed Res Int. 2017;8068725.

60. Lv Z, Wang S, Zhang F, Chen L, Hao X, Pan Q, et al. Overexpression of a novel NAC domain-containing transcription factor gene (AaNAC1) enhances the content of artemisinin and increases tolerance to drought and Botrytis cinerea in Artemisia annua. Plant Cell Physiol. 2016;57(9):1961-71.

61. Fang $Y$, Liao $K$, Du $H, X u Y$, Song $H$, Li X, et al. A stress-responsive NAC transcription factor SNAC3 confers heat and drought tolerance through modulation of reactive oxygen species in rice. J Exp Bot. 2015;66(21):6803-17.

62. Hu H, Dai M, Yao J, Xiao B, Li X, Zhang Q, et al. Overexpressing a NAM, ATAF, and CUC (NAC) transcription factor enhances drought resistance and salt tolerance in rice. Proc Natl Acad Sci U S A. 2006;103(35):12987-92. 
63. Zhang JY, Qu SC, Qiao YS, Zhang Z, Guo ZR. Overexpression of the Malus hupehensis MhNPR1 gene increased tolerance to salt and osmotic stress in transgenic tobacco. Mol Biol Rep. 2014;41(3):1553-61.

64. Wang $N$, Xiao B, Xiong L. Identification of a cluster of PR4-like genes involved in stress responses in rice. J Plant Physiol. 2011;168 (18):2212-24.

65. Misra RC, Sandeep, Kamthan M, Kumar S, Ghosh S A thaumatin-like protein of Ocimum basilicum confers tolerance to fungal pathogen and abiotic stress in transgenic Arabidopsis Sci Rep 2016;6:25340.

66. Wu J, Kim SG, Kang KY, Kim JG, Park SR, Gupta R. Overexpression of a pathogenesis-related protein 10 enhances biotic and abiotic stress tolerance in rice. Plant Pathol J. 2016;32(6):552-62.

67. Jung YJ, Melencion SM, Lee ES, Park JH1, Alinapon CV, Oh HT et al Universal stress protein exhibits a redox-dependent chaperone function in Arabidopsis and enhances plant tolerance to heat shock and oxidative stress Front Plant Sci 2015;6:1141.

68. Fleischmann F, Koehl J, Portz R, Beltrame AB, Oßwald W. Physiological changes of Fagus sylvatica seedlings infected with Phytophthora citricola and the contribution of its elicitin 'citricolin' to pathogenesis. Plant Biol. 2005;7(6):650-8.

69. Clemenz C, Fleischmann F, Haberle KH, Matyssek R, Oßwald W. Photosynthetic and leaf water potential responses of Alnus glutinosa saplings to stem-base inoculation with Phytophthora alni subsp. alni. Tree Physiol. 2008;18(11):1703-11.

70. Martínez-Ferri E, Zumaquero A, Ariza MT, Barceló-Muñoz A, Pliego C. Nondestructive detection of white root rot disease in avocado rootstocks by leaf chlorophyll fluorescence. Plant Dis. 2016;100(1):49-58.

71. Galmés J, Abadía A, Cifre J, Medrano H, Flexas J. Photoprotection processes under water stress and recovery in Mediterranean plants with different growth forms and leaf habits. Physiol Plant. 2007;130:495-510.

72. Xu Z, Zhou G, Shimizu H. Plant responses to drought and rewatering. Plant Signal Behav. 2010;5(6):649-54.

73. Chartzoulakis K, Patakas A, Kofidis G, Bosabalidis A, Nastou A. Water stress affects leaf anatomy, gas exchange, water relations and growth of two avocado cultivars. Sci Hortic. 2002;95(1-2):39-50.

74. Moreno-Ortega G, Pliego C, Sarmiento D, Barceló A, Martínez-Ferri E. Yield and fruit quality of avocado trees under different regimes of water supply in the subtropical coast of Spain. Agric Water Manag. 2019;221:192-201.

75. Flexas J, Bota J, Galmés J, Medrano H, Ribas-Carbó M. Keeping a positive carbon balance under adverse conditions: responses of photosynthesis and respiration to water stress. Physiol Plant. 2006;127(3):343-52.

76. Resco V, Ewers BE, Sun W, Huxman TE, Weltzin JF, Williams DG. Droughtinduced hydraulic limitations constrain leaf gas exchange recovery after precipitation pulses in the C3 woody legume, Prosopis velutina New Phytol 2009;181(3):672-682.

77. Maxwell K, Johnson GN. Chlorophyll fluorescence- a practical guide. J Exp Bot. 2000;51(345):659-68.

78. Chen D, Wang S, Cao B, Cao D, Leng G, Li H, et al. Genotypic variation in growth and physiological response to drought stress and re-watering reveals the critical role of recovery in drought adaptation in maize seedlings. Front Plant Sci. 2016;6:1241.

79. Nardini A, Salleo S. Limitation of stomatal conductance by hydraulic traits: sensing or preventing xylem cavitation? Trees. 2000;15(1):14-24

80. Neuhaus A, Turner DW, Colmer TD, Kuo J, Eastham J. Drying half the rootzone of potted avocado (Persea americana mill., cv. Hass) trees avoids the symptoms of water deficit that occur under complete root-zone drying. J Hortic Sci Biotechnol. 2007:82(5):679-89.

81. Pliego C, Kanematsu S, Ruano-Rosa D, de Vicente A, López-Herrera C, Cazorla FM, et al. GFP sheds light on the infection process of avocado roots by Rosellinia necatrix. Fungal Genet Biol. 2009;46(2):137-45.

82. Hu R, Qi G, Kong Y, Kong D, Gao Q, Zhou G. Comprehensive analysis of NAC domain transcription factor gene family in Populus trichocarpa. BMC Plant Biol. 2010;10(1):145.

83. Ding Y, Fromm M, Avramova Z. Multiple exposures to drought 'train' transcriptional responses in Arabidopsis. Nat Commun. 2012;3:740.

84. Loukehaich R, Wang T, Ouyang B, Ziaf K, Li H, Zhang J, et al. SpUSP, an annexin-interacting universal stress protein, enhances drought tolerance in tomato. J Exp Bot. 2012;63(15):5593-606.

85. Bassett CL, Baldo AM, Moore JT, Jenkins RM, Soffe DS, Wisniewski ME, et al. Genes responding to water deficit in apple (Malus $x$ domestica Borkh.) roots. BMC Plant Biol. 2014;14:182.
86. Gonçalves LP, Boscariol Camargo RL, Takita MA, Machado MA, Dos Soares Filho WS, Costa MGC. Rootstock-induced molecular responses associated with drought tolerance in sweet orange as revealed by RNA-Seq. BMC Genomics. 2019;20(1):110.

87. Brunner I, Herzog C, Dawes MA, Arend M, Sperisen C. How tree roots respond to drought. Front Plant Sci. 2015;6:547.

88. Jiang CJ, Shimono M, Sugano S, Kojima M, Yazawa K, Yoshida R, et al. Abscisic acid interacts antagonistically with salicylic acid signaling pathway in rice-Magnaporthe grisea. Mol Plant-Microbe Interact. 2010;23(6):791-8.

89. Ali S, Ganai BA, Kamili AN, Bhat AA, Mir ZA, Bhat JA, et al. Pathogenesisrelated proteins and peptides as promising tools for engineering plants with multiple stress tolerance. Microbiol Res. 2018;212-213:29-37.

90. Backer R, Naidoo S, van den Berg N. The nonexpressor of pathogenesisrelated genes 1 (NPR1) and related family: mechanistic insights in plant disease resistance. Front Plant Sci. 2019;10:102.

91. Suleman P, Al-Musallam A, Menezes CA. The effect of solute potential and water stress on black scorch caused by Chalara paradoxa and Chalara radicicola on date palms. Plant Dis. 2001;85(1):80-3.

92. Bostock RM, Pye MF, Roubtsova TV. Predisposition in plant disease: exploiting the nexus in abiotic and biotic stress perception and response. Annu Rev Phytopathol. 2014;52:517-49.

93. Ramegowda V, Senthil-Kumar M. The interactive effects of simultaneous biotic and abiotic stresses on plants: mechanistic understanding from drought and pathogen combination. J Plant Physiol. 2015;176:47-54.

94. Takatsuji H. Regulating tradeoffs to improve rice production. Front Plant Sci. 2017;8:171.

95. Robert-Seilaniantz A, Navarro L, Bari R, Jones JD. Pathological hormone imbalances. Curr Opin Plant Biol. 2007;10(4):372-9.

96. López MA, Bannenberg G, Castresana C. Controlling hormone signaling is a plant and pathogen challenge for growth and survival. Curr Opin Plant Biol. 2008;11(4):420-7.

97. Grant MR, Jones JD. Hormone (dis) harmony moulds plant health and disease. Science. 2009;324(5928):750-2.

98. Gupta A, Hisano H, Hojo Y, Matsuura T, Ikeda Y, Mori IC, et al. Global profiling of phytohormone dynamics during combined drought and pathogen stress in Arabidopsis thaliana reveals ABA and JA as major regulators. Sci Rep. 2017;7(1):4017.

99. Zhang $X$, Lei L, Lai J, Zhao H, Song W. Effects of drought stress and water recovery on physiological responses and gene expression in maize seedlings. BMC Plant Biol. 2018;18(1):68.

100. Walia H, Wilson C, Condamine P, Liu X, Ismail AM, Zeng L, et al. Comparative transcriptional profiling of two contrasting rice genotypes under salinity stress during the vegetative growth stage. Plant Physiol. 2005; 139(2):822-35.

101. Bertini L, Caporale C, Testa M, Proietti S, Caruso C. Structural basis of the antifungal activity of wheat PR4 proteins. FEBS Lett. 2009;583(17):2865-71.

102. Wang X, Basnayake BM, Zhang H, Li G, Li W, Virk N, et al. The Arabidopsis ATAF1, a NAC transcription factor, is a negative regulator of defense responses against necrotrophic fungal and bacterial pathogens. Mol PlantMicrobe Interact. 2009;22(10):1227-38.

103. Udawat $P$, Jha RK, Sinha D, Mishra A, Jha B. Overexpression of a cytosolic abiotic stress responsive universal stress protein (SbUSP) mitigates salt and osmotic stress in transgenic tobacco plants. Front Plant Sci. 2016;7:518.

104. Xie Q, Frugis G, Colgan D, Chua NH. Arabidopsis NAC1 transduces auxin signal downstream of TIR1 to promote lateral root development. Genes Dev. 2000 Dec 1;14(23):3024-36.

105. Fu Y, Guo H, Cheng Z, Wang R, Li G, Huo G, Liu W. NtNAC-R1, a novel NAC transcription factor gene in tobacco roots, responds to mechanical damage of shoot meristem. Plant Physiol Biochem. 2013;69:74-81.

106. Frolich EF, Platt RG. Use of the etiolation technique in rooting avocado cuttings. California Avocado Soc. 1972;55:97-109.

107. Hsiao TC-Measurements of plant water status. In: Stewart BA, Nielsen DR editors. Irrigation of Agricultural Crops. Monograph No. 30. Madison, Wl: American Society of Agronomy;1990. p. 243-279.

108. Uddling J, Gelang-Alfredsson J, Piikki K, Pleijel H. Evaluating the relationship between leaf chlorophyll concentration and SPAD-502 chlorophyll meter readings. Photosynth Res. 2007;91(1):37-46.

109. Schreiber U, Bilger W, Neubauer C. Chlorophyll fluorescence as a nonintrusive indicator for rapid assessment of in vivo photosynthesis. In: Schulze ED, Caldwell MM, editors. Ecophysiology of Photosynthesis vol 100. Springer Study Edition. Berlin: Springer; 1995. p 49-70. 
110. Genty B, Briantais JM, Baker NR. The relationship between the quantum yield of photosynthetic electron transport and quenching of chlorophyll fluorescence. Biochimica et Biophysica Acta (BBA). 1989;990(1):87-92.

111. Bilger W, Björkman O. Role of the xanthophyll cycle in photoprotection elucidated by measurements of light-induced absorbance changes, fluorescence and photosynthesis in leaves of Hedera canariensis. Photosynth Res. 1990;25(3):173-95.

112. von Caemmerer S, Farquhar GD. Some relationships between the biochemistry of photosynthesis and the gas exchange of leaves. Planta. 1981;153(4):376-87.

113. Chang S, Puryear J, Cairney J. A simple and efficient method for isolating RNA from pine trees. Plant Mol Biol Rep. 1993;11(2):113-6.

114. Untergasser A, Cutcutache I, Koressaar T, Ye J, Faircloth BC, Remm M, et al. Primer3--new capabilities and interfaces. Nucleic Acids Res. 2012;40(15):e115.

115. Koressaar T, Remm M. Enhancements and modifications of primer design program Primer3. Bioinformatics. 2007;23(10):1289-91.

116. Pfaffl MW. A new mathematical model for relative quantification in real-time RT-PCR. Nucleic Acids Res. 2001;29(9):e45.

117. Sztejnberg A, Madar Z. Host range of Dematophora necatrix, the cause of white root rot disease in fruit trees. Plant Dis. 1980;64:662-4.

118. Teixeira de Sousa AJ. Lutte contre Rosellinia necatrix (Hartig) Berlese, agent du "pourridié laineux": Sensibilité de quelques espèces végétales et lutte chimique. Eur J For Pathol. 1985;15:323-32.

119. Campbell CL, Madden LV. Temporal analysis of epidemics. I: Descriptions and comparisons of disease progress curve. In: Campbell CL, Madden LV, editors. NY: Wiley; 1990. p 161-162.

\section{Publisher's Note}

Springer Nature remains neutral with regard to jurisdictional claims in published maps and institutional affiliations.

Ready to submit your research? Choose BMC and benefit from:

- fast, convenient online submission

- thorough peer review by experienced researchers in your field

- rapid publication on acceptance

- support for research data, including large and complex data types

- gold Open Access which fosters wider collaboration and increased citations

- maximum visibility for your research: over $100 \mathrm{M}$ website views per year

At $\mathrm{BMC}$, research is always in progress.

Learn more biomedcentral.com/submissions 